\title{
Bioerosive impact of Diadema mexicanum on southern Mexican Pacific coral reefs
}

\section{Impacto bioerosivo de Diadema mexicanum en arrecifes de coral del Pacífico sur mexicano}

\author{
Andrés López-Pérez ${ }^{1 *}$, Daniel A López-López ${ }^{2}$ \\ ${ }^{1}$ Laboratorio de Ecosistemas Costeros, Departamento de Hidrobiología, Universidad Autónoma \\ Metropolitana-Iztapalapa, San Rafael Atlixco 186, Col. Vicentina, Del. Iztapalapa, 09340 Ciudad de México, \\ México. \\ 2 Programa de Posgrado en Ecología Marina, Universidad del Mar, 70902 Puerto Ángel, Oaxaca, México. \\ * Corresponding author. E-mail: alopez@xanum.uam.mx
}

\begin{abstract}
Reef ecosystem growth and maintenance is closely related to sea urchin feeding activities. Hence, quantifying the bioerosive capacity of the sea urchin Diadema mexicanum is necessary to evaluate its impact on coral communities and reefs that develop off the Pacific coast of southern Mexico. Sea urchin density, size, bioerosion rate, and type of carbonate removed were estimated, and the carbonate budget of 15 coral communities and reefs found off Guerrero and Oaxaca was calculated. Sea urchin density $(H=13.4, P=0.001)$ and size $(H=139.5$, $P=0.000$ ) varied over space and were significantly (density, $r^{2}=0.79, P=0.00$; size, $r^{2}=0.28, P=0.03$ ) related to substrate characteristics. In general, size (test diameter) and density were directly related to rock coverage but inversely related to live coral cover. Carbonate removal was directly related to sea urchin size $(<3.4 \mathrm{~cm}=0.052 \mathrm{~g} / \mathrm{ind} / \mathrm{d}, 3.4-6.1 \mathrm{~cm}=0.202 \mathrm{~g} / \mathrm{ind} / \mathrm{d},>6.1 \mathrm{~cm}=0.325 \mathrm{~g} /$ ind $/ \mathrm{d})$. Of the total carbonate removed, $22 \%$ corresponded to aragonite and $78 \%$ to magnesium calcite, indicating that sea urchin impact on coral reef skeletons is small. When reef carbonate budget was calculated, only $3.1 \%$ of the total carbonate deposited by reef corals was removed. The above data indicate that sea urchin feeding activity alone does not compromise reef ecosystem growth and maintenance in southwestern Mexico. Nonetheless, in the near future, the current policy of use and development in and around reef systems may boost the bioerosive impact of $D$. mexicanum in the area.
\end{abstract}

Key words: carbonate budget, corals, sea urchins, bioerosion, Mexico.

RESUMEN. El crecimiento y mantenimiento de los ecosistemas arrecifales está relacionado con la actividad alimenticia de los erizos de mar. Así, determinar la capacidad bioerosiva del erizo Diadema mexicanum es necesaria para evaluar su impacto en las comunidades y arrecifes de coral que se desarrollan frente a las costas del Pacífico del sur de México. Este estudio evaluó la densidad, la talla y la tasa de bioerosión de D. mexicanum y el tipo de carbonato removido, a partir de lo cual se estimó el balance de carbonatos en 15 comunidades y arrecifes coralinos ubicados frente a Guerrero y Oaxaca. La densidad $(H=13.4, P=0.001)$ y la talla $(H=139.5, P=0.000)$ de los erizos varió espacialmente y ambos parámetros estuvieron relacionados significativamente (densidad, $r^{2}=0.79, P=0.00$; talla, $r^{2}=0.28, P=0.03$ ) con las características del sustrato. En general, los organismos alcanzaron mayor talla y densidad en sitios con mayor cobertura de roca y baja cobertura de coral vivo. La remoción de carbonatos estuvo directamente relacionada con la talla de los erizos $(<3.4 \mathrm{~cm}=0.052 \mathrm{~g} / \mathrm{ind} / \mathrm{d}, 3.4-6.1 \mathrm{~cm}=0.202 \mathrm{~g} / \mathrm{ind} / \mathrm{d}$, $>6.1 \mathrm{~cm}=0.325 \mathrm{~g} / \mathrm{ind} / \mathrm{d}$ ). Del total de carbonatos removidos, el $22 \%$ correspondió a aragonita coralina y el $78 \%$ a calcita de magnesio, lo que sugiere que el impacto de los erizos sobre el esqueleto de los corales en la región es mínimo. El balance entre acumulación y remoción de aragonita coralina indicó que esta última fue sólo el $3.1 \%$ del total de carbonatos depositado por los corales, indicando que la actividad alimenticia del erizo, por si misma, no compromete el crecimiento y permanencia de las comunidades y arrecifes coralinos en las costas sudoccidentales de México. No obstante, la actual política de uso y de desarrollo en, y alrededor de, los sistemas arrecifales en la región podría exacerbar el efecto bioerosivo de D. mexicanum en un futuro próximo.

Palabras clave: balance de carbonatos, corales, erizos, bioerosión, México.

\section{INTRODUCTION}

The growth and maintenance of coral reef communities depend on a dynamic process that involves the accumulation and removal of carbonates over time (Goldber 2013). Carbonate removal largely results from bioerosion, which involves the dissolution and excavation of carbonates by a variety of bioeroding organisms of reef systems, notably

\section{INTRODUCCIÓN}

El crecimiento y mantenimiento de las comunidades y arrecifes de coral dependen de un proceso dinámico que involucra la acumulación y la remoción de carbonatos a través del tiempo (Goldber 2013). Una parte importante de la remoción de carbonatos es causada por la bioerosión, que involucra la disolución y/o la excavación de carbonato por 
sponges (Nava and Carballo 2008), polychaetes (Hutchings 2008), molluscs (Kiene and Hutchings 1994), fish (Bruggemann et al. 1996), and sea urchins (Glynn 1988, Perry et al. 2012).

The feeding activity of sea urchins has been shown to be relevant in reef systems because of their capacity to control algal communities (Carpenter 1986, Hughes et al. 1987) and facilitate coral recruitment (Sammarco 1980). Moreover, sea urchins are known to play a role in carbon removal (Glynn 1988, Reaka-Kudla et al. 1996) and, thus, in the growth and maintenance of reef ecosystems (Bellwood et al. 2004).

In the Tropical Eastern Pacific, studies have been conducted on the bioerosion rate of the sea urchins Toxopneustes roseus, Eucidaris thouarsii, and Diadema mexicanum (Glynn 1988, Reaka-Kudla et al. 1996, Reyes-Bonilla and CalderónAguilera 1999, Herrera-Escalante et al. 2005) and on their role in coral reefs of Mexico (Gulf of California, Oaxaca), Costa Rica, Panama, and the Galapagos Islands. Because of its ability to remove cabonates (Glynn 1988, Reaka-Kudla et al. 1996), its high abundance (Glynn and Leyte-Morales 1997, Herrera-Escalante et al. 2005, Alvarado et al. 2012), and gregarious behavior (Levitan 1988), D. mexicanum is considered the most relevant echinoderm in reef ecosystems of the eastern Pacific (Alvarado et al. 2015).

In southwestern Mexico, carbonate removal associated with the grazing activity of $D$. mexicanum has been estimated to be up to $4 \mathrm{~kg} / \mathrm{m}^{2} / \mathrm{yr}$ in Bahías de Huatulco, Oaxaca (Herrera-Escalante et al. 2005). This estimate, however, can vary considerably depending on the temporal changes in sea urchin abundance (Benítez-Villalobos et al. 2008). Despite previous studies in Ixtapa-Zihuatanejo, Guerrero (LópezPérez et al. 2012), and in Puerto Ángel, Oaxaca (LeyteMorales 1997, Reyes-Bonilla and Leyte-Morales 1998), data on carbonate removal by sea urchins are lacking for extensive and important coral sections. On the other hand, the carbonate removal estimated for D. mexicanum at Bahías de Huatulco considered the total carbonates without analyzing the composition of the eroded material (Glynn 1988). The latter is of vital importance because how sea urchins affect the analyzed system will depend on the type of material removed. For example, if $D$. mexicanum primarily removes calcareous material deposited by algae (magnesium calcite), which is rapidly replaced during algal growth, then the effect on the coralline skeleton will be minimal. Conversely, a high aragonite content in the eroded material indicates that grazing by $D$. mexicanum is having a damaging effect on the coral structure. Hence, the objective of the present study was to determine the effect of the feeding activity of $D$. mexicanum on coral reefs and communities in three areas on the Pacific coast of southern Mexico: Ixtapa-Zihuatanejo, Puerto Ángel, and Bahías de Huatulco. In addition to estimating carbonate removal, the composition of the eroded material (magnesium calcite $v s$ aragonite) was examined to more precisely determine the effect of the sea urchin on the coral systems of the region. organismos, entre los cuales se encuentran los principales macro bioerosionadores de los sistemas arrecifales, como las esponjas (Nava y Carballo 2008), poliquetos (Hutchings 2008), moluscos (Kiene y Hutchings 1994), peces (Bruggemann et al. 1996) y erizos de mar (Glynn 1988, Perry et al. 2012).

La actividad alimenticia de los erizos de mar ha sido recurrentemente señalada como relevante dentro de los sistemas arrecifales debido a la capacidad de los erizos para controlar las comunidades algales (Carpenter 1986, Hughes et al. 1987) y facilitar el reclutamiento coralino (Sammarco 1980). Adicionalmente, los erizos han sido reconocidos por su rol en la remoción de carbonatos (Glynn 1988, Reaka-Kudla et al. 1996) y, en última instancia, en el crecimiento y mantenimiento de los ecosistemas arrecifales (Bellwood et al. 2004).

En el Pacífico Oriental Tropical, se ha estudiado la tasa de bioerosión de los erizos de mar Toxopneustes roseus, Eucidaris thouarsii y Diadema mexicanum (Glynn 1988, Reaka-Kudla et al. 1996, Reyes-Bonilla y Calderón-Aguilera 1999, Herrera-Escalante et al. 2005) y su relevancia en las comunidades y arrecifes coralinos de México (golfo de California, Oaxaca), Costa Rica, Panamá y las islas Galápagos. Debido a su capacidad para remover carbonatos (Glynn 1988, Reaka-Kudla et al. 1996), su alta abundancia (Glynn y Leyte-Morales 1997, Herrera-Escalante et al. 2005, Alvarado et al. 2012) y su comportamiento gregario (Levitan 1988), D. mexicanum es considerado como el equinodermo más relevante en los ecosistemas arrecifales del Pacífico oriental (Alvarado et al. 2015).

En las costas del Pacífico del sur de México, se ha estimado que la remoción de carbonatos por la actividad alimenticia de $D$. mexicanum alcanza hasta $4 \mathrm{~kg} / \mathrm{m}^{2} /$ año en Bahías de Huatulco (Herrera-Escalante et al. 2005). Dicha estimación, sin embargo, puede cambiar de manera importante en función de las modificaciones temporales de la abundancia del erizo (Benítez-Villalobos et al. 2008). A pesar de los estudios anteriores, en Ixtapa-Zihuatanejo, Guerrero (López-Pérez et al. 2012), y en Puerto Ángel, Oaxaca (LeyteMorales 1997, Reyes-Bonilla y Leyte-Morales 1998), existen extensas e importantes porciones coralinas para las cuales se carece de datos respecto al papel que desempeñan los erizos en la remoción de carbonatos. Por otro lado, cabe resaltar que en la estimación de remoción de carbonatos para D. mexicanum en Bahías de Huatulco se consideraron los carbonatos totales pero no se analizó la composición del material erosionado (Glynn 1988). Lo anterior es de vital importancia, pues dependiendo del tipo de material removido, será el efecto del erizo sobre el sistema analizado. Por ejemplo, si D. mexicanum remueve predominantemente material calcáreo depositado por algas (calcita de magnesio), el cual es reemplazado rápidamente durante el crecimiento algal, entonces el efecto de los erizos sobre el esqueleto de los corales será mínimo. Por el contrario, si el contenido de aragonita en el material erosionado es importante, la actividad alimenticia de los erizos podría causar un daño 


\section{MATERIALS AND METHODS}

\section{Study area}

The study was carried out from September 2008 to August 2009 at 15 sites located in the states of Guerrero and Oaxaca, southwestern Mexico (Fig. 1). The sites were grouped into three areas (extreme coordinates of $15^{\circ} 39^{\prime} 42.76^{\prime \prime} \mathrm{N}$ and $17^{\circ} 40^{\prime} 49.21^{\prime \prime} \mathrm{N}$ and $96^{\circ} 07^{\prime} 41.50^{\prime \prime} \mathrm{W}$ and $\left.101^{\circ} 39^{\prime} 32.43^{\prime \prime} \mathrm{W}\right)$ : the area of Ixtapa-Zihuatanejo (Guerrero) comprised the sites of Morros del Cerro Colorado, Zacatoso, El Chato, Caleta de Chon, and Manzanillo; the area of Puerto Ángel (Oaxaca) comprised the sites of Mazunte, Estacahuite, La Mina, Playa del Muerto, and La Tijera; and the area of Bahías de Huatulco (Oaxaca) comprised the sites of San Agustín, Riscalillo, Isla Cacaluta, Violín, and La Entrega. In all cases, the fringing coral reefs and/or communities, of varying size, were located in bays or behind rocks that protected them from wave action, at depths not exceeding $12 \mathrm{~m}$. Their substrate characteristics are shown in Table 1. The coral communities in the study area are dominated by importante en la estructura coralina. Considerando lo anterior, el presente estudio tiene como objetivo determinar el efecto de la actividad alimenticia del erizo de mar D. mexicanum en comunidades y arrecifes coralinos localizados en tres zonas de la costa sudoccidental (océano Pacífico) de México: Ixtapa-Zihuatanejo, Puerto Ángel y Bahías de Huatulco. Para tal fin, además de estimar la remoción de carbonatos, se analizó la composición (calcita de magnesio vs aragonita) del material erosionado con el fin de obtener una estimación más precisa del efecto del erizo sobre los sistemas coralinos de la región.

\section{MATERIALES Y MÉTODOS}

\section{Área de estudio}

El estudio se realizó de septiembre de 2008 a agosto de 2009 en 15 sitios ubicados en los estados de Guerrero y Oaxaca, México (Fig. 1). Los sitios se agruparon en tres zonas (coordenadas extremas de $15^{\circ} 39^{\prime} 42.76^{\prime \prime} \mathrm{N}$ y $17^{\circ} 40^{\prime} 49.21^{\prime \prime} \mathrm{N}$ y $96^{\circ} 07^{\prime} 41.50^{\prime \prime} \mathrm{W}$ y $101^{\circ} 39^{\prime} 32.43^{\prime \prime} \mathrm{W}$ ): la zona
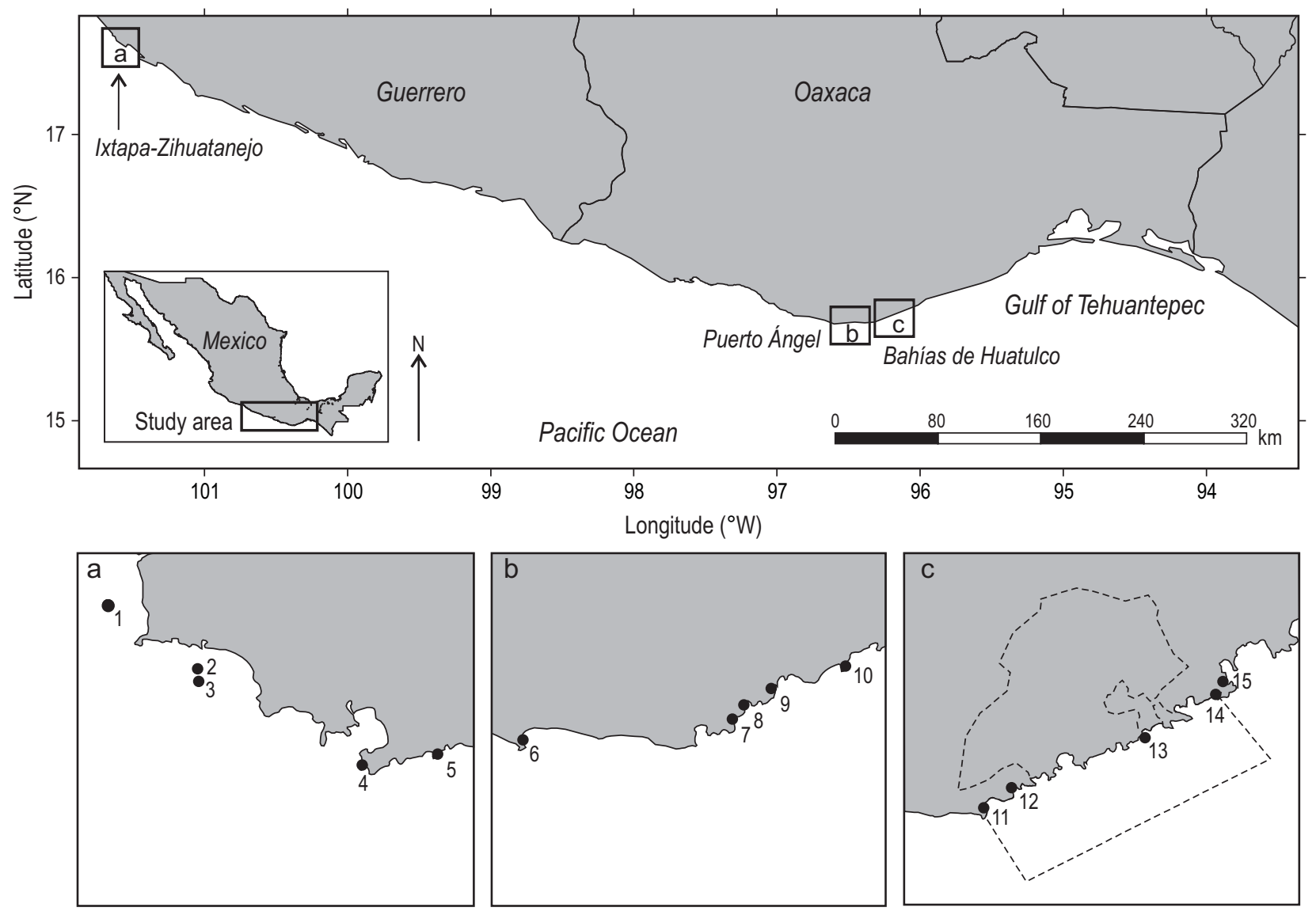

Figure 1. Location of sampling sites along the coast of Guerrero and Oaxaca, southwestern Mexico.

Figura 1. Ubicación de los sitios de muestreo en la costa de Guerrero y Oaxaca, sudoeste de México.

1. Morros del Cerro Colorado, 2. El Chato, 3. Zacatoso, 4. Caleta de Chon, 5. Manzanillo, 6. Mazunte, 7. Estacahuite, 8. La Mina, 9. Playa del Muerto, 10. La Tijera, 11. San Agustín, 2. Riscalillo, 13. Isla Cacaluta, 14. Violín, 15. La Entrega. 
Pocillopora spp. ( $>90 \%)$ and to a lesser extent by Pavona spp. $(<5 \%)$ and Porites spp. $(<1 \%)$ (Glynn and LeyteMorales 1997; Reyes-Bonilla and Leyte-Morales 1998; López-Pérez et al. 2012, 2014). For a more detailed description of the species composition, substrate cover, size, depth, and other details of these systems see López-Pérez et al. (2012) for those in Ixtapa-Zihuatanejo; Reyes-Bonilla and Leyte-Morales (1998) for those in Puerto Ángel; and Glynn and Leyte-Morales (1997), López-Pérez et al. (2014), and Santiago-Valentín et al. (2015) for those in Bahías de Huatulco.

\section{Data collection}

To determine the bioerosive impact of $D$. mexicanum on coral reefs and coral communities off Guerrero and Oaxaca, we analyzed the population structure of this sea urchin, its relation to the substrate characteristics, and the proportion of coralline aragonite removed by size class.

The sea urchin population density (ind $/ \mathrm{m}^{2}$ ) and percent cover of five substrate types (coral by genus, algae, dead coral, rocks, and sand) were obtained by laying out four line transects $(20 \times 1 \mathrm{~m})$ at each site, except at Playa del Muerto, where only two transects were laid due to space restrictions. Along the transects, the percent cover of each substrate type was determined visually every square meter using a $1 \mathrm{~m}^{2}$ quadrat with $10 \times 10 \mathrm{~cm}$ grids. The size of the transects was chosen to allow comparisons with previous studies (e.g., Reyes-Bonilla and Calderón-Aguilera 1999, HerreraEscalante et al. 2005, Benítez-Villalobos et al. 2008, Alvarado et al. 2012) and ongoing studies in the Tropical Eastern Pacific. The number of transects were the same at all sites and considered adequate because the area of all of them, except for La Entrega that covers an area of $\sim 3.2$ ha, does not exceed 2 ha. At each site, the transects were laid out randomly over the reef structure, parallel to the coastline, and within the bathymetric distribution range of coral communities $(0-12 \mathrm{~m})$. Concurrently, the test diameter $( \pm 0.01 \mathrm{~cm})$ of up to 50 randomly-selected individuals of $D$. mexicanum within the transects was recorded in situ in order to determine the size structure for each site.

The amount of coralline aragonite $\left(\mathrm{g} \mathrm{CaCO}_{3} / \mathrm{ind} / \mathrm{d}\right)$ and magnesium calcite $\left(\mathrm{g} \mathrm{MgCO}_{3} / \mathrm{ind} / \mathrm{d}\right)$ removed by sea urchin size class (class $1,<3.4 \mathrm{~cm}$; class 2, 3.4-6.1 cm; class 3 , $>6.1 \mathrm{~cm}$ ) was determined by analyzing the feces of 33 randomly-chosen sea urchins at one previously-selected site (Estacahuite). This sampling scheme assumes that grazing and, consequently, carbonate removal by $D$. mexicanum is relatively homogeneous among individuals of the same size inhabiting different localities but that there are differences in terms of the size of individuals.

Feces were collected and analyzed following the method proposed by Glynn (1988). Coralline aragonite is lightly stained a pink color and magnesium calcite (i.e., coralline algae) an orange color. This makes it easier to differentiate de Ixtapa-Zihuatanejo (Guerrero) estuvo conformada por los sitios Morros del Cerro Colorado, Zacatoso, El Chato, Caleta de Chon y Manzanillo; la zona de Puerto Ángel (Oaxaca) estuvo conformada por Mazunte, Estacahuite, La Mina, Playa del Muerto y La Tijera; y la zona de Bahías de Huatulco (Oaxaca) estuvo conformada por San Agustín, Riscalillo, isla Cacaluta, Violín y La Entrega. En todos los casos, se trata de comunidades y/o arrecifes coralinos de tipo franja (extensión variable), localizados en bahías o detrás de rocas que los protegen del oleaje, que no exceden los $12 \mathrm{~m}$ de profundidad. Su tipo de fondo se muestran en la Tabla 1. Las comunidades coralinas del área de estudio están dominadas por Pocillopora spp. (>90\%) y en menor medida por Pavona spp. $(<5 \%)$ y Porites spp. $(<1 \%)$ (Glynn y Leyte-Morales 1997; Reyes-Bonilla y Leyte-Morales 1998; López-Pérez et al. 2012, 2014). Para una descripción más detallada de la composición de especies, cobertura, extensión, profundidad y otros datos particulares, se puede consultar a López-Pérez et al. (2012) para los sistemas que se desarrollan en IxtapaZihuatanejo; Reyes-Bonilla y Leyte-Morales (1998) para aquellos ubicados en la zona de Puerto Ángel; y Glynn y Leyte-Morales (1997), López-Pérez et al. (2014) y SantiagoValentín et al. (2015) para los sistemas que se localizan en Bahías de Huatulco.

\section{Obtención de datos}

Para determinar el impacto bioerosivo de D. mexicanum en arrecifes y comunidades arrecifales de las costas sudoccidentales de México, se consideró la estructura poblacional del erizo, su relación con las características del sustrato y la proporción de aragonita coralina removida por clase de talla.

La densidad poblacional (ind $/ \mathrm{m}^{2}$ ) de D. mexicanum y la cobertura (\%) de las características del sustrato (corales por género, algas, coral muerto, rocas y arena) se obtuvieron mediante cuatro transectos de banda $(20 \times 1 \mathrm{~m})$ en cada sitio; excepto en Playa del Muerto, donde el tamaño reducido del sitio impidió realizar más de dos transectos. En los transectos, el porcentaje de cobertura de cada característica del sustrato se determinó de manera visual cada metro cuadrado utilizando un cuadrante de $1 \mathrm{~m}^{2}$ con cuadrículas de $10 \times 10 \mathrm{~cm}$. La dimensión de los transectos fue elegida para garantizar la comparación respecto a estudios previos (e.g., Reyes-Bonilla y Calderón-Aguilera 1999, HerreraEscalante et al. 2005, Benítez-Villalobos et al. 2008, Alvarado et al. 2012) y estudios en curso en el Pacífico Oriental Tropical. El número de transectos por sitio se mantuvo constante entre sitios y puede considerarse adecuado debido a que el área de los sistemas, excepto La Entrega que tiene $\sim 3.2 \mathrm{ha}$, no rebasa las 2 ha. Los transectos se colocaron aleatoriamente sobre la estructura arrecifal, paralelos a la línea de costa y dentro del intervalo de distribución batimétrica de las comunidades coralinas $(0-12 \mathrm{~m})$ en cada sitio. Concurrentemente, se registró in situ el diámetro testal $( \pm 0.01 \mathrm{~cm})$ de hasta 50 individuos de $D$. mexicanum elegidos 


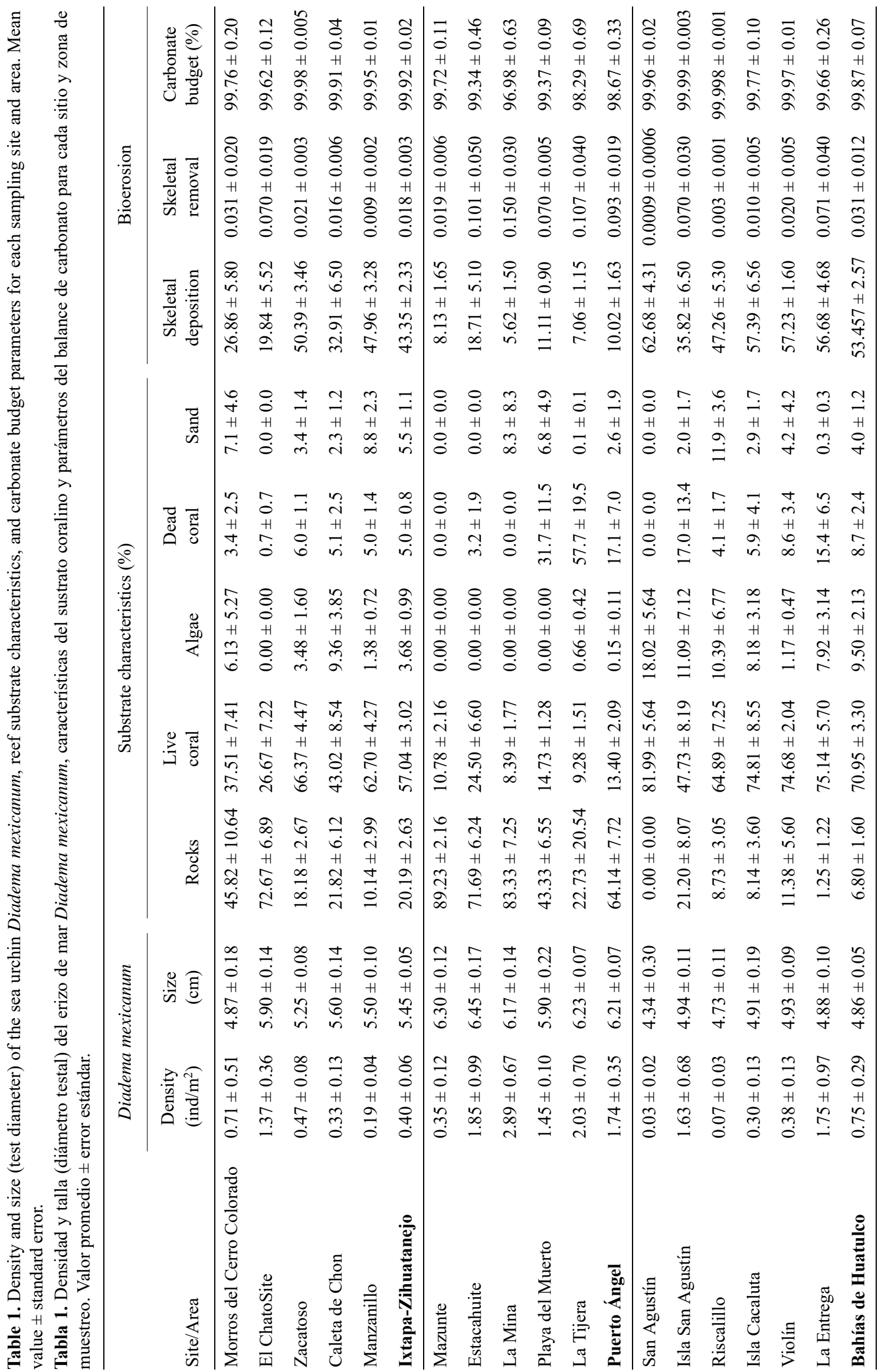


these carbonate forms and allows a more accurate estimate of the carbonate removed by $D$. mexicanum from the coral reefs in the study area.

We estimated the balance between the input and removal of carbonates in the coral reefs. Input was estimated considering the coverage data (see above, Table 1), linear extension rate (Guzmán and Cortés 1989a, Jiménez and Cortés 2003), and density (Glynn and Macintyre 1977, Hughes 1987) for each coral genus recorded at each site according to Perry et al. (2012). Removal was estimated considering density, size structure, and the content of coralline aragonite and magnesium calcite in sea urchin feces following the method proposed by Herrera-Escalante et al. (2005).

\section{Data analysis}

We examined whether the sea urchin density and size data complied with the assumptions of normality and homogeneity of variance. As they did not, the differences between areas (Ixtapa-Zihuatanejo, Puerto Ángel, Bahías de Huatulco) and between the sites located within them were assessed by a Kruskal-Wallis nonparametric analysis of variance, followed by the Nemenyi a posteriori test (Zar 2009).

Two methods were used to assess the degree of association between the substrate characteristics and the density and size of $D$. mexicanum. The first method consisted of analyzing the correlation between individual variables with the Spearman rank test. The second method consisted of performing linear regression analysis to assess the relation between the scores obtained for the sites by principal coordinates analysis of the substrate characteristics and sea urchin abundance and size data.

To determine whether one type of carbonate was predominantly removed by sea urchins, the data of the coralline aragonite and magnesium calcite contained in the feces were compared by a Mann-Whitney U test.

Finally, we performed a Kruskal-Wallis nonparametric analysis of variance, followed by the Nemenyi a posteriori test (Zar 2009), to (a) determine whether the amount of carbonate (coralline aragonite, magnesium calcite) varied between sea urchin sizes and (b) assess the spatial differences in carbonate input and removal among areas and among the sites located within them.

\section{RESULTS}

Spatial analysis of the sea urchin density data revealed significant differences between areas $(H=13.4, P=0.001)$. Puerto Ángel had a significantly higher density of sea urchins $(Q=2.394)$ than Bahías de Huatulco and Ixtapa-Zihuatanejo (Table 1). At a local scale, there were no significant differences among the sites located in Ixtapa-Zihuatanejo $(H=7.1$, $P=0.13)$ and Puerto Ángel $(H=8.5, P=0.07)$. While significant differences were observed for Bahías de Huatulco ( $H=17.4, P=0.003)$, the $a$ posteriori test was unable to discern among which sites these differences occurred. al azar en los transectos con el fin de determinar la estructura de talla para cada sitio.

La cantidad de aragonita coralina $\left(\mathrm{g} \mathrm{CaCO}_{3} /\right.$ ind/d) y calcita de magnesio $\left(\mathrm{g} \mathrm{MgCO}_{3} / \mathrm{ind} / \mathrm{d}\right)$ removida por clase de talla (clase $1,<3.4 \mathrm{~cm}$; clase 2, 3.4-6.1 cm; clase 3, $>6.1 \mathrm{~cm}$ ) se determinó a partir del análisis de las heces de 33 individuos de $D$. mexicanum elegidos al azar en un sitio (Estacahuite) elegido aleatoriamente. Este esquema de muestreo supone que la actividad alimenticia y, por consiguiente, la remoción de carbonatos por parte de $D$. mexicanum es relativamente homogénea entre individuos de la misma talla que habitan sitios distintos, pero presenta diferencias en función de la talla de los individuos.

Para la obtención de las heces y el análisis de las mismas, se siguió el método de Glynn (1988). Mediante este método, la aragonita coralina se tiñe ligeramente de rosa y la calcita de magnesio (i.e., algas coralinas) de color naranja. Lo anterior facilita la diferenciación entre estas formas de carbonatos y permite una estimación más precisa del carbonato que D. mexicanum remueve de las comunidades y arrecifes coralinos en el área de estudio.

Se estimó el balance entre el depósito y la remoción de carbonatos en las comunidades y arrecifes coralinos de las costas sudoccidentales de México. Para estimar el depósito, se consideraron datos de cobertura (ver arriba, Tabla 1), tasa de extensión lineal (Guzmán y Cortés 1989a, Jiménez y Cortés 2003) y densidad (Glynn y Macintyre 1977, Hughes 1987) por cada género de coral registrado en cada sitio siguiendo el método utilizado por Perry et al. (2012). Por su parte, la remoción se estimó a partir de los datos de densidad, estructura de talla y contenido de aragonita coralina y calcita de magnesio en las heces de los erizos siguiendo la metodología propuesta por Herrera-Escalante et al. (2005).

\section{Análisis de datos}

Se evaluó si los datos de densidad y talla de D. mexicanum cumplían con los supuestos de normalidad y homogeneidad de varianza. Como los datos no cumplieron con los supuestos, las diferencias entre zonas (IxtapaZihuatanejo, Puerto Ángel, Bahías de Huatulco) y entre sitios dentro de las zonas se evaluaron mediante un análisis de varianza no paramétrico de Kruskal-Wallis, seguido de una prueba a posteriori de Nemenyi (Zar 2009).

El grado de asociación entre las características del sustrato y la densidad y talla de $D$. mexicanum se evaluó mediante dos métodos. El primer método consistió en analizar la correlación entre las variables individuales mediante una prueba por rangos de Spearman. Para el segundo método, se utilizó un análisis de regresión lineal simple para evaluar la relación entre la puntuación de los sitios obtenida mediante el análisis de coordenadas principales de las características del sustrato y los datos de abundancia y talla de los erizos.

Para evaluar si alguno de los tipos de carbonatos removidos por los erizos era predominante, los datos de aragonita 
Regarding sea urchin size, the analysis revealed significant differences $(H=139.5, P=0.00)$ in test diameters between areas $(Q=2.394)$. The test diameter of the individuals was significantly higher in Puerto Ángel, followed by Ixtapa-Zihuatanejo, and lastly Bahías de Huatulco (Table 1). At a smaller spatial scale, the diameter differed among the sites in Ixtapa-Zihuatanejo $(H=25.21, P=0.00)$ and Bahías de Huatulco $(H=11.68, P=0.01)$. In Ixtapa-Zihuatanejo, the diameter of the sea urchins collected from Manzanillo differed significantly $(Q=2.807)$ from those found at Zacatoso, El Chato, and Morros del Cerro Colorado (Table 1). In the case of Bahías de Huatulco, the a posteriori test was unable to identify significant differences between the diameters of the sea urchins from the different sites.

According to the principal coordinates analysis, the ordination of the study sites and areas based on substrate characteristics can be described by the first two components (PCO1 and PCO2), which contributed $96.6 \%$ of the total variation (PCO1, 74.3\%; PCO2, 22.3\%) (Fig. 2a). The ordination of the sites shows a gradient running from the Bahías de Huatulco area (left side of the plot), through the IxtapaZihuatanejo area, to the Puerto Ángel area (right side of the plot). This gradient is mainly related to spatial variation in the percentage of coral cover (left portion of the ordination) and rock cover (right portion of the ordination). That is, coral cover is relevant in the Bahías de Huatulco area but loses relevancy towards the Puerto Ángel area where rock cover increases. The other substrate characteristics were not relevant in the ordination.

Analysis of the data revealed that there was a significant relation between the scores of the first component (PCO1) and the size of $D$. mexicanum $\left(r^{2}=0.79, P=0.00\right)$ (Fig. $2 b$ ), as well as between the scores and density of sea urchins $\left(r^{2}=0.28, P=0.03\right.$ ) (Fig. 2c). The latter indicates that $79 \%$ of the spatial variation in sea urchin size and $28 \%$ of the spatial variation in sea urchin density may be explained by the characteristics of the substrate at each site. That is, the size and density of the organisms is larger at sites with greater rock cover (e.g., Puerto Ángel area) and scant live coral cover. The density of sea urchins is inversely and significantly correlated with coral cover (Spearman $r=-0.59$, $n=15, P<0.05$ ) and with the abundance of algae (Spearman $r=-0.53, n=15, P<0.05)$, but directly correlated with the presence of rocks (Spearman $r=0.53, n=15, P<0.05$ ). The diameter of the sea urchins is inversely and significantly correlated with coral cover (Spearman $r=-0.82, n=15$, $P<0.05$ ) and algal cover (Spearman $r=-0.81, n=15$, $P<0.05$ ), and directly correlated with the presence of rocks (Spearman $r=0.78, n=15, P<0.05$ ).

Total carbonate removal was directly proportional to sea urchin size (class $1=0.052 \mathrm{~g} / \mathrm{ind} / \mathrm{d}$, class $2=0.202 \mathrm{~g} / \mathrm{ind} / \mathrm{d}$, class $3=0.325 \mathrm{~g} / \mathrm{ind} / \mathrm{d}$ ); hence, small individuals removed a smaller amount of carbonates than larger individuals. Of the total carbonate removed by sea urchins, $22 \%$ corresponded to coralline aragonite and $78 \%$ to magnesium calcite; the latter coralina y calcita de magnesio contenidos en las heces se compararon mediante una prueba $\mathrm{U}$ de Mann-Whitney.

Finalmente, se empleó un análisis de varianza no paramétrico de Kruskal-Wallis, seguido de una prueba $a$ posteriori de Nemenyi (Zar 2009), para (a) evaluar si la cantidad removida de cada especie de carbonato (aragonita coralina, calcita de magnesio) variaba entre tallas del erizo y (b) evaluar las diferencias espaciales en el depósito y remoción de carbonatos entre zonas y entre sitios dentro de las zonas.

\section{RESUltados}

El análisis espacial de los datos de densidad de D. mexicanum evidenció que existen diferencias significativas entre zonas $(H=13.4, P=0.001)$. Puerto Ángel presentó una densidad de erizos significativamente mayor $(Q=2.394)$ que Bahías de Huatulco e Ixtapa-Zihuatanejo (Tabla 1). A escala local, en las zonas de Ixtapa-Zihuatanejo $(H=7.1$, $P=0.13)$ y Puerto Ángel $(H=8.5, P=0.07)$ no ocurrieron diferencias significativas entre sitios. Aunque en Bahías de Huatulco $(H=17.4, P=0.003)$ ocurrieron diferencias significativas entre sitios, la prueba a posteriori fue incapaz de discernir entre qué sitios ocurrieron las diferencias.

Respecto a la talla de los organismos, el análisis reveló que existen diferencias significativas $(H=139.5, P=0.00)$ en el diámetro de la testa de los erizos entre todas las zonas $(Q=2.394)$. El diámetro de la testa de los erizos fue significativamente mayor en Puerto Ángel, seguido de IxtapaZihuatanejo y finalmente de Bahías de Huatulco (Tabla 1). A una escala espacial menor, se detectó que el diámetro de los erizos difirió entre los sitios ubicados en Ixtapa-Zihuatanejo $(H=25.21, P=0.00)$ y Bahías de Huatulco $(H=11.68, P=$ 0.01). En Iztapa-Zihuatanejo, el diámetro de los erizos que habitan en Manzanillo difirió significativamente $(Q=2.807)$ de los que habitan en Zacatoso, El Chato y Morros del Cerro Colorado (Tabla 1). Para Bahías de Huatulco, la prueba a posteriori fue incapaz de identificar diferencias significativas entre los diámetros de los erizos que habitan distintos sitios.

Mediante el análisis de coordenadas principales, la ordenación de los sitios y las zonas en función de las características del sustrato puede ser descrita a partir de los primeros dos componentes (PCO1 y $\mathrm{PCO} 2$ ), los cuales contribuyeron con el 96.6\% de la variación total (PCO1, 74.3\%; PCO2, 22.3\%) (Fig. 2a). La ordenación indicó que existe un gradiente de sitios que va desde la zona de Bahías de Huatulco (parte izquierda del diagrama) hasta la zona de Puerto Ángel (parte derecha del diagrama), pasando por los sitios que comprenden la zona de Ixtapa-Zihuatanejo. El gradiente está relacionado principalmente con la variación espacial en el porcentaje de cobertura de corales (porción izquierda de la ordenación) y en la cobertura de roca (porción derecha de la ordenación). Es decir, la cobertura de corales es relevante en la zona de Bahías de Huatulco, pero pierde relevancia hacia la zona de Puerto Ángel donde se incrementa la cobertura 


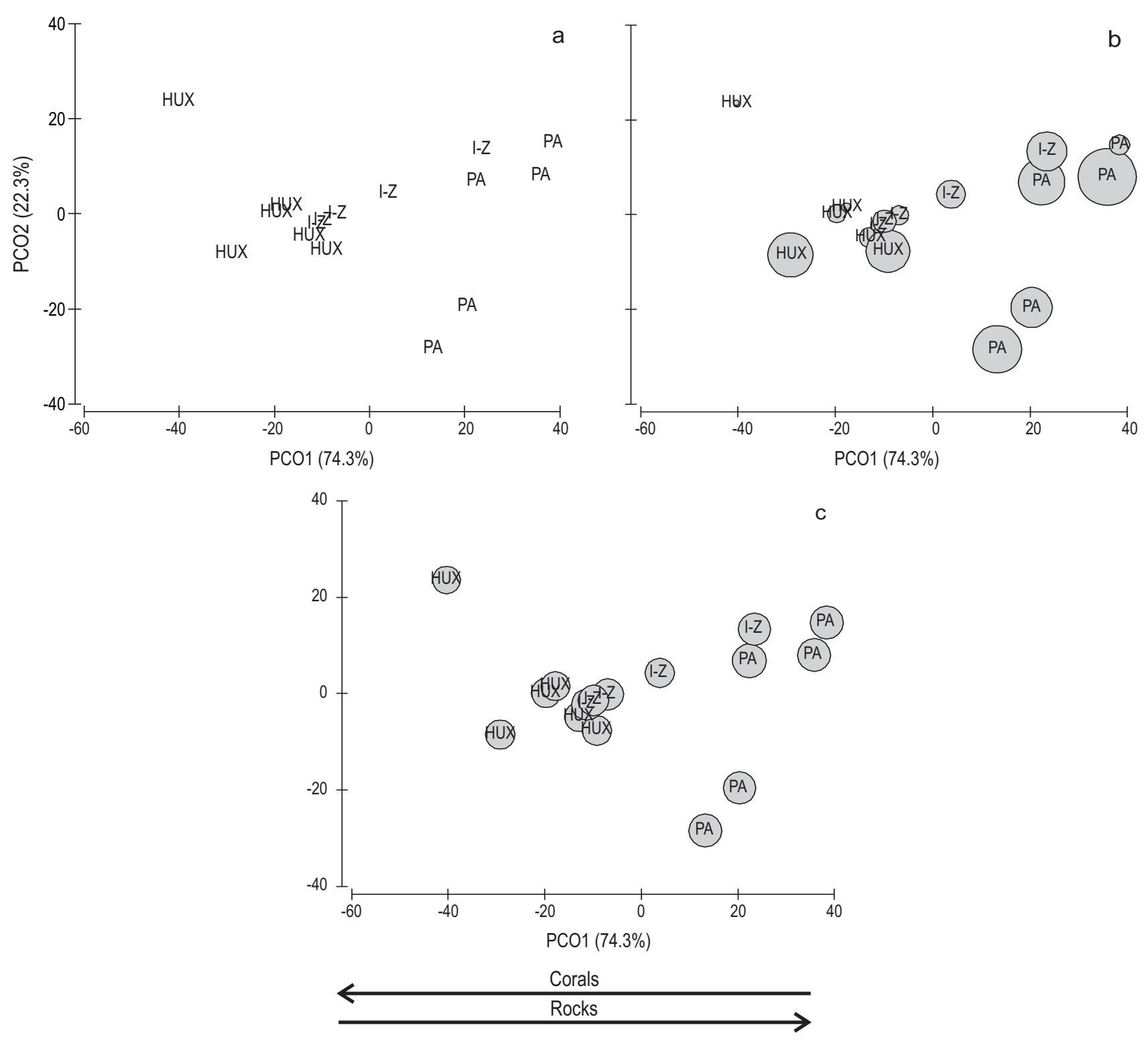

Figure 2. Ordination of sampling sites and areas by principal coordinates analysis: (a) ordination of sampling sites and areas based on substrate characteristics, (b) ordination of sampling sites and areas based on substrate characteristics and their relation to sea urchin size, (c) ordination of sampling sites and areas based on substrate characteristics and their relation to sea urchin density. I-Z = Ixtapa-Zihuatanejo, Guerrero; PA = Puerto Ángel, Oaxaca; HUX = Bahías de Huatulco, Oaxaca. Bubbles refer to relative sea urchin size and density at each sampling site. Arrow direction refers to the importance of corals and rocks in the ordination.

Figura 2. Ordenación de los sitios y las zonas de muestreo mediante un análisis de coordenadas principales: (a) ordenación de los sitios y las zonas con base en las características del sustrato, (b) ordenación de los sitios y las zonas con base en las características del sustrato y su relación con la talla de los erizos de mar, (c) ordenación de los sitios y las zonas con base en las características del sustrato y su relación con la densidad de erizos de mar. I-Z = Ixtapa-Zihuatanejo, Guerrero; PA = Puerto Ángel, Oaxaca; HUX = Bahías de Huatulco, Oaxaca. Los círculos indican la talla y densidad relativas de los erizos de mar. La dirección de las flechas indica la importancia de corales y rocas en la ordenación.

was also significantly higher than the former $(t=-6.21, P=$ $0.000)$. With regard to removal by carbonate type and sea urchin size, the same relation is observed as for total carbonate, that is, the removal of both coralline aragonite and magnesium calcite was directly proportional to the size of the individuals. de roca. Las otras características del sustrato no fueron relevantes en la ordenación.

Por otro lado, el análisis de datos reveló que existe una relación significativa entre la puntuación del primer componente (PCO1) de la ordenación y la talla de $D$. mexicanum $\left(r^{2}=0.79, P=0.00\right)($ Fig. $2 b)$, así como entre la puntuación y 
The rate of carbonate accumulation in coral reefs and communities was significantly different $(H=47.17, P=$ $0.00)$ among areas $(Q=2.39)$. Bahías de Huatulco had the highest rate of accumulation, followed by Ixtapa-Zihuatanejo and Puerto Ángel (Table 1). Significant differences were observed among the Ixtapa-Zihuatanejo sites $(H=14.81$, $P=0.005)$ and among the Puerto Ángel sites $(H=10.42, P=$ $0.03)$, but not among the Bahías de Huatulco sites $(H=8.50$, $P=0.13)$. In Puerto Ángel, differences were observed among all the sites $(Q=2.80)$. In Ixtapa-Zihuatanejo $(Q=2.80)$, the accumulation rates were significantly higher in Zacatoso and Manzanillo than in El Chato, Morros del Cerro Colorado, and Caleta de Chon (Table 1), while Zacatoso presented higher accumulation than Manzanillo.

The rate of carbonate removal due to the feeding activity of $D$. mexicanum was significantly different among areas $(H=24.78, P=0.00)$. The removal rate was higher in Puerto Ángel $(Q=2.39)$, followed by Bahías de Huatulco and Ixtapa-Zihuatanejo (Table 1). The removal rate among sites varied significantly in Ixtapa-Zihuatanejo $(H=11.96, P=$ $0.01)$ and Bahías de Huatulco $(H=12.17, P=0.03)$, but not among the Puerto Ángel sites $(H=8.37, P=0.07)$. In IxtapaZihuatanejo $(Q=2.39)$, there were significant differences among all sites, except between Morros del Cerro Colorado and El Chato. In Bahías de Huatulco $(Q=2.93)$, La Entrega differed significantly from the other sites, Cacaluta differed from Violín and San Agustín, and Riscalillo differed from San Agustín (Table 1).

Finally, the balance between the accumulation and removal of coralline aragonite showed that only $3.1 \%$ of the aragonite deposited was removed in the Puerto Ángel area, where bioerosion was more intense. More modest values were obtained for Bahías de Huatulco, followed by IxtapaZihuatanejo. Hence, in the coral reefs in our study area, net accumulation of coralline aragonite $(\sim 96.9 \%)$ was much higher than removal $(\sim 3.1 \%)$ caused by the feeding activity of D. mexicanum in all the areas (Table 1).

\section{DISCUSSION}

The results showed that the removal of carbonates associated with the feeding activity of $D$. mexicanum represents a small fraction $(\sim 3.2 \%)$ of the total of carbonates deposited by reef builders off the Pacific coast of southern Mexico. This suggests that grazing by this species does not compromise the growth and permanence of coral reefs and communities in Ixtapa-Zihuatanejo in Guerrero and in Puerto Ángel and Bahías de Huatulco in Oaxaca. Our findings are contrary to those obtained in the 1980s by Glynn (1988) in Panama and by Guzmán and Cortés (1989b) in Costa Rica, where D. mexicanum was found to actively erode the coral systems. They are, however, in agreement with that reported by ReyesBonilla and Calderón-Aguilera (1999) for Cabo Pulmo, by Herrera-Escalante et al. (2005) and Benítez-Villalobos et al. (2008) for Huatulco, and by Alvarado et al. (2012) for Isla la densidad de erizos $\left(r^{2}=0.28, P=0.03\right)$ (Fig. 2c). Lo anterior indica que las variaciones espaciales de la talla (79\%) y la densidad (28\%) de los erizos pudieran estar explicadas por las características del sustrato de cada sitio. Es decir, los organismos alcanzaron mayor talla y densidad en sitios con mayor cobertura de roca (e.g., Puerto Ángel) y baja cobertura de coral vivo. De manera individual, la densidad de erizos se correlacionó inversa y significativamente con la cobertura coralina ( $r$ de Spearman $=-0.59, n=15, P<0.05)$ y la abundancia de algas $(r$ de Spearman $=-0.53, n=15, P<0.05)$, pero directamente con la presencia de rocas $(r$ de Spearman $=$ $0.53, n=15, P<0.05$ ). El diámetro de los individuos de $D$. mexicanum se correlacionó inversa y significativamente con la cobertura de coral $(r$ de Spearman $=-0.82, n=15$, $P<0.05)$ y algas $(r$ de Spearman $=-0.81, n=15, P<0.05)$ y directamente con la presencia de rocas $(r$ de Spearman $=$ $0.78, n=15, P<0.05)$.

La remoción de carbonatos totales fue directamente proporcional a la talla del organismo (clase $1=0.052 \mathrm{~g} / \mathrm{ind} / \mathrm{d}$, clase $2=0.202 \mathrm{~g} / \mathrm{ind} / \mathrm{d}$, clase $3=0.325 \mathrm{~g} / \mathrm{ind} / \mathrm{d}$ ), de tal forma que los individuos pequeños removieron menor cantidad de carbonatos que los individuos grandes. Del total de carbonatos removidos por los erizos, el $22 \%$ correspondió a aragonita coralina y el $78 \%$ a calcita de magnesio; esta última fue significativamente mayor que la primera $(t=-6.21, P=0.000)$. Respecto a la remoción por tipo de carbonato y talla, se observó la misma relación que para los carbonatos totales, es decir, tanto la remoción de aragonita coralina como la de calcita de magnesio fueron directamente proporcionales a la talla de los individuos.

La tasa de acumulación de carbonatos en comunidades y arrecifes coralinos presentó diferencias significativas $(H=47.17, P=0.00)$ entre todas las zonas $(Q=2.39)$. Bahías de Huatulco presentó la mayor tasa de acumulación, seguida de Ixtapa-Zihuatanejo y Puerto Ángel (Tabla 1). Se detectaron diferencias significativas entre los sitios de IxtapaZihuatanejo $(H=14.81, P=0.005)$ y Puerto Ángel $(H=$ $10.42, P=0.03)$, pero no entre los sitios de Bahías de Huatulco $(H=8.50, P=0.13)$. En Puerto Ángel $(Q=2.80)$ las diferencias ocurrieron entre todos los sitios. En IxtapaZihuatanejo $(Q=2.80)$, las tasas de acumulación en Zacatoso y Manzanillo fueron significativamente mayores que en El Chato, Morros del Cerro Colorado y Caleta de Chon (Tabla 1); Zacatoso por su parte, presentó una tasa de acumulación mayor que Manzanillo.

Respecto a la tasa de remoción de carbonatos por la actividad alimenticia de $D$. mexicanum en comunidades y arrecifes coralinos, se observaron diferencias significativas entre zonas $(H=24.78, P=0.00)$. La tasa de remoción fue mayor en Puerto Ángel $(Q=2.39)$, seguido de Bahías de Huatulco e Ixtapa-Zihuatanejo (Tabla 1). La tasa de remoción varió significativamente entre los sitios de IxtapaZihuatanejo $(H=11.96, P=0.01)$ y los sitios de Bahías de Huatulco $(H=12.17, P=0.03)$, pero no entre los sitios de Puerto Ángel $(H=8.37, P=0.07)$. En Ixtapa-Zihuatanejo 
Cocos, Isla Caño, and Bahía Culebra in Costa Rica, where the carbonates removed by sea urchins represented a small fraction of the carbonates deposited by reef builders.

Contrary to the daily removal values previously recorded for $D$. mexicanum in the eastern Pacific, those obtained in the present study $(0.52-0.324 \mathrm{~g} / \mathrm{ind} / \mathrm{d})$ were lower than those recorded in Panama (1.98 g/ind/d, Glynn 1988), Huatulco ( $2.08 \mathrm{~g} / \mathrm{ind} / \mathrm{d}$, Herrera-Escalante et al. 2005), and Costa Rica (0.56-2.25 g/ind/d, Alvarado et al. 2012). Our daily removal values translate into an annual impact of $0.03 \mathrm{~kg} / \mathrm{m}^{2} / \mathrm{yr}$ on the coral reefs and communities of southwestern Mexico, which represents, when compared with lower annual removal values, only $17 \%$ of that recorded in other reefs of the region (Panama, 3.47-10.4 kg/m²/yr, Glynn 1988; Huatulco, $0.17-4 \mathrm{~kg} / \mathrm{m}^{2} / \mathrm{yr}$, Herrera-Escalante et al. 2005, BenítezVillalobos et al. 2008; Costa Rica, 0.31-0.75 kg/m²/ $/ \mathrm{yr}$, Alvarado et al. 2012).

Annual carbonate removal by $D$. mexicanum in coral reefs of southwestern Mexico is closely linked to the feeding activity of this species (Glynn 1988) and its variation depending on sea urchin size (Herrera-Escalante et al. 2005). Carbonate removal is also associated with sea urchin density levels, the spatial distribution patterns (i.e., clustering) of the individuals, and their spatial distribution in the different reef zones (Hawkins 1981, Bak 1994, Woodley 1999). Our estimated value for total carbonate content in the feces of $D$. mexicanum as a function of size falls within the values reported for other other Diadema spp. found in the Caribbean and Pacific Ocean (Perry et al. 2012). However, when the type of carbonate removed is considered, the diet of D. mexicanum includes only $\sim 6-22 \%$ of coralline aragonite and the rest corresponds to magnesium calcite. Our results differ strongly from those obtained by Glynn (1988) in Panama, where $D$. mexicanum removed a greater proportion $(\sim 75 \%)$ of coralline aragonite. The difference between values can be attributed to different methodologies, though part of the variation could be the result of differences in the type of substrate on which the species grazes or to spatial differences in its feeding habits. Glynn (1988) observed that bioerosion by $D$. mexicanum was two-fold higher on dead coral than on live coral. The effect of grazing by $D$. mexicanum off southwestern Mexico may be closely linked to the state of conservation of the coral reefs studied. Hence, reefs with large areas of dead coral experience high levels of aragonite removal and vice versa. Moreover, the combined effect of enhanced aragonite removal related to the state of conservation, increased sea urchin density, and the gregarious behavior of D. mexicanum (Levitan 1988) may exacerbate bioerosion of the reef structure. The findings of studies carried out in Costa Rica, Panama, and the Galapagos Islands after the El Niño 1982-1983 event (Glynn 1988, Guzmán and Cortés 1992, Eakin 1996, Reaka-Kudla et al. 1996, Alvarado et al. 2012) show that impoverishment of the state of conservation of the coral community promotes erosional processes. In southwestern Mexico, coral reefs and communities in the area of
$(Q=2.39)$, las diferencias ocurrieron entre todos los sitios, excepto entre Morros del Cerro Colorado y El Chato. En Bahías de Huatulco $(Q=2.93)$, La Entrega difirió significativamente del resto de los sitos, Cacaluta de Violín y San Agustín, y Riscalillo de San Agustín (Tabla 1).

Por último, el balance entre acumulación y remoción de aragonita coralina indicó que esta última fue de sólo 3.1\% del total depositado en Puerto Ángel, donde la remoción fue más intensa. No obstante, valores más modestos se observaron en Bahías de Huatulco, seguido de Ixtapa-Zihuatanejo. Así, en los arrecifes que se desarrollan frente a las costas sudoccidentales de México, la acumulación neta de aragonita coralina $(\sim 96.9 \%)$ fue mucho mayor que la remoción $(\sim 3.1 \%)$ por la actividad alimenticia de D. mexicanum en todas las zonas (Tabla 1).

\section{DISCUSIÓN}

Los resultados mostraron que la remoción de carbonatos por la actividad alimenticia de $D$. mexicanum representa una pequeña fracción $(\sim 3.2 \%)$ del total de carbonatos depositados por los corales constructores de arrecife frente a las costas del Pacífico del sur de México. Lo anterior sugiere que la actividad alimenticia de esta especie no compromete el crecimiento y permanencia de las comunidades y arrecifes coralinos en Ixtapa-Zihuatanejo en Guerrero y en Puerto Ángel y Bahías de Huatulco en Oaxaca. Así, lo aquí reportado es opuesto a lo observado en los años de la década de 1980 en Panamá por Glynn (1988) y en Costa Rica por Guzmán y Cortés (1989b), en donde se registró que D. mexicanum erosionó activamente los sistemas coralinos de la región. Sin embargo, nuestros resultados concuerdan con lo reportado por Reyes-Bonilla y Calderón-Aguilera (1999) para cabo Pulmo, por Herrera-Escalante et al. (2005) y Benítez-Villalobos et al. (2008) para Huatulco y por Alvarado et al. (2012) para isla Cocos, isla Caño y bahía Culebra en Costa Rica, en donde se observó que los carbonatos removidos por los erizos representan una pequeña fracción de lo depositado por los corales constructores de arrecifes.

Contrario a los valores de remoción diaria previamente registrados para $D$. mexicanum en el Pacífico oriental, los observados durante el presente estudio $(0.52-0.324 \mathrm{~g} / \mathrm{ind} / \mathrm{d})$ fueron menores que los encontrados en Panamá $(1.98 \mathrm{~g} / \mathrm{ind} / \mathrm{d}$, Glynn 1988), Huatulco (2.08 g/ind/d, Herrera-Escalante et al. 2005) y Costa Rica (0.56-2.25 g/ind/d, Alvarado et al. 2012). Los valores de la remoción diaria estimados en el presente estudio se traducen en un impacto anual de $0.03 \mathrm{~kg} / \mathrm{m}^{2} /$ año en las comunidades y arrecifes coralinos del sudoeste de México, lo que representa, cuando se contrasta con los valores de remoción anual más bajos, sólo el 17\% de lo registrado para otros arrecifes de la región (Panamá, $3.47-10.4 \mathrm{~kg} / \mathrm{m}^{2} /$ año, Glynn 1988; Huatulco, 0.17-4 kg/m²/año, HerreraEscalante et al. 2005, Benítez-Villalobos et al. 2008; Costa Rica, $0.31-0.75 \mathrm{~kg} / \mathrm{m}^{2} /$ año, Alvarado et al. 2012). 
Acapulco in Guerrero (López-Pérez et al. 2012), and in Puerto Escondido (López-Pérez, unpublished data), Puerto Ángel (Reyes-Bonilla and Leyte-Morales 1998), and Bahías de Huatulco in Oaxaca (Glynn and Leyte-Morales 1997, López-Pérez and Hernández-Ballesteros 2004), may have experienced rapid bioerosion after the deterioration of the systems as a result, primarily, of human activities, though data are lacking to confirm this.

In general, the density of $D$. mexicanum in the coral reefs and communities of southwestern Mexico does not differ from, or is slightly below, the values reported for other reef systems in the Tropical Eastern Pacific (Alvarado and Fernández 2005, Herrera-Escalante et al. 2005, BenítezVillalobos et al. 2008, Alvarado et al. 2012). In our study area, significant differences were observed in the density of D. mexicanum at different spatial scales. The spatial distribution of sea urchin density and size may be explained by the variation in substrate characteristics. In particular, the density and size of $D$. mexinanum were greater at those sites with lower coral and algal cover but greater rock presence. These results may indicate the potential present and future effects of bioerosion by $D$. mexicanum on coral reefs of southwestern Mexico. The highest levels of bioerosion caused by sea urchin grazing were recorded in Puerto Ángel (Oaxaca) and the lowest in Ixtapa-Zihuatanejo (Guerrero). If the present levels of use and state of conservation of the coral systems off the Pacific coast of southern Mexico persist, bioerosion is likely to increase in the area of Puerto Ángel, especially at sites such as La Tijera and Playa del Muerto where large patches $(>30 \%)$ of dead coral are observed.

Finally, it is important to take into consideration that the present study addresses only the potential effects of the feeding activity of $D$. mexicanum on coral reefs and communities but does not address the bioerosion associated with the mechanical abrasion of sea urchin spines (Herrera-Escalante et al. 2005). Moreover, the data presented here do not consider the bioerosion caused by sponges (Nava and Carballo 2008; Carballo et al. 2008, 2013), fish (Ong and Holland 2010), molluscs, and other macro and micro bioeroders (Perry et al. 2012) that also contribute to the removal of carbonates from reef ecosystems.

\section{ACKNOWLEDGMENTS}

The present study was supported by funds from the National Council for Science and Technology (CONACYT, Mexico, projects 80228 and 236654) and Universidad Autónoma Metropolitana (PRODEP UAM-PTC-509) to ALP. DALL acknowledges financial support from CONACYT (CVU 477189). We thank Eladio Spindola and Andrés Pacheco (Universidad del Mar) for their assistance with the field work.

English translation by Christine Harris.
La remoción anual de D. mexicanum en las comunidades y arrecifes coralinos de las costas del Pacífico del sur de México está íntimamente ligada a la actividad alimenticia de la especie (Glynn 1988) y a su variación en función de la talla (Herrera-Escalante et al. 2005). La remoción, además, está asociada a los niveles de densidad, los patrones de distribución espacial (i.e., agregación) y la distribución espacial de los erizos en las distintas zonas del arrecife (Hawkins 1981, Bak 1994, Woodley 1999). El valor del contenido de carbonatos totales en las heces de $D$. mexicanum en función de la talla se encuentra dentro de los valores observados para otras especies de Diadema que ocurren en el Caribe y en el océano Pacífico (Perry et al. 2012). Sin embargo, cuando se considera el tipo de carbonato removido, la dieta de $D$. mexicanum incluye sólo $\sim 6-22 \%$ de aragonita coralina, mientras que el porcentaje restante corresponde a calcita de magnesio. Los resultados del presente estudio contrastan marcadamente con lo observado por Glynn (1988) en Panamá, donde D. mexicanum removió una mayor proporción $(\sim 75 \%)$ de aragonita coralina. La asimetría entre los valores obedece a diferencias metodológicas, aunque una parte de la variación pudiera resultar de las diferencias en el tipo de sustrato en donde la especie lleva a cabo su actividad alimenticia o las diferencias espaciales en los hábitos alimenticios de la especie. Glynn (1988) observó que la bioerosión de D. mexicanum es dos veces mayor en sustrato de coral muerto que en coral vivo. En perspectiva, el efecto de la actividad alimenticia de D. mexicanum en las costas del Pacífico del sur de México pudiera estar íntimamente ligado con el estado de conservación de los sistemas estudiados. Así, comunidades y arrecifes con grandes extensiones de coral muerto experimentarán niveles de remoción de aragonita coralina elevados y viceversa. Además, el efecto combinado entre los mayores niveles de remoción de aragonita coralina relacionados al estado de conservación, el aumento de la densidad y el comportamiento gregario de D. mexicanum (Levitan 1988) podrían exacerbar la bioerosión de la estructura arrecifal. Lo reportado para Costa Rica, Panamá y las islas Galápagos posterior al evento de El Niño 1982-1983 (Glynn 1988, Guzmán y Cortés 1992, Eakin 1996, ReakaKudla et al. 1996, Alvarado et al. 2012) representan ejemplos donde un empobrecimiento en el estado de conservación de la comunidad coralina promueve procesos erosivos relevantes. En el caso de las costas del Pacífico del sur de México, comunidades y arrecifes coralinos en el área de Acapulco en Guerrero (López-Pérez et al. 2012) y Puerto Escondido (López-Pérez, datos sin publicar), Puerto Ángel (ReyesBonilla y Leyte-Morales 1998) y Bahías de Huatulco en Oaxaca (Glynn y Leyte-Morales 1997, López-Pérez y Hernández-Ballesteros 2004) pudieran haber experimentado una rápida bioerosión luego del deterioro del estado de conservación producto, principalmente, de la actividad humana en la región, aunque carecemos de datos para confirmarlo.

En términos generales, la densidad de D. mexicanum en las comunidades y arrecifes coralinos de las costas del 


\section{REFERENCES}

Alvarado JJ, Cortés J, Reyes-Bonilla H. 2012. Reconstruction of Diadema mexicanum A. Agassiz, 1863 bioerosion impact on three Costa Rican Pacific coral reefs. Rev. Biol. Trop. 60 (Sup. 2): 121-132.

Alvarado JJ, Fernández C. 2005. Equinodermos del Parque Nacional Marino Ballena, Pacífico, Costa Rica. Rev. Biol. Trop. 53 (Sup. 3): 275-284.

Alvarado JJ, Reyes-Bonilla H, Benítez-Villalobos F. 2015. Diadema mexicanum, erizo de mar clave en los arrecifes coralinos del Pacífico Tropical Oriental: Estado de conocimiento y perspectivas futuras. Rev. Biol. Trop. 63 (Sup. 2): 135-157.

Bak RPM. 1994. Sea urchin bierosion on coral reefs: Place in the carbonate budget and relevant variables. Coral Reefs 13: 99-103.

Bellwood DR, Hughes TP, Folke C, Nyström M. 2004. Confronting the coral reef crisis. Nature 429: 827-833.

Benítez-Villalobos F, Domínguez y Gómez MT, López-Pérez RA. 2008. Temporal variation of the sea urchin Diadema mexicanum population density at Bahías de Huatulco, western Mexico. Rev. Biol. Trop. 56(3): 255-263.

Bruggemann JH, van Kessel AM, van Rooij JM, Breeman AM. 1996. Bioerosion and sediment ingestion by the Caribbean parrotfish Scarus vetula and Sparisoma viridae: Implications of fish size, feeding mode and habitat use. Mar. Ecol. Prog. Ser. 134: 59-71.

Carballo JL, Bautista E, Nava H, Cruz-Barraza JA, Chávez JA. 2013. Boring sponges, an increasing threat for coral reefs affected by bleaching events. Ecol. Evol. 3(4): 872-886.

Carballo JL, Bautista-Guerrero E, Leyte-Morales GE. 2008. Boring sponges and modeling of coral reefs in the East Pacific Ocean. Mar. Ecol. Prog. Ser. 356: 113-122.

Carpenter RC. 1986. Partitioning herbivory and its effects on coral reef algal communities. Ecol. Monogr. 56: 345-363.

Eakin CM. 1996. Where have all the carbonate gone? A model comparison of calcium carbonate budgets before and after the 1982-1983 El Niño at Uva Island in the Eastern Pacific. Coral Reefs 15: 109-119.

Glynn PW. 1988. El Niño warming, coral mortality and reef framework destruction by echinoid bioerosion in the Eastern Pacific. Galaxea 7: 129-160.

Glynn PW, Leyte-Morales GE. 1997. Coral reef of Huatulco, west Mexico: Reef development in upwelling Gulf of Tehuantepec. Rev. Biol. Trop. 45: 1033-1048.

Glynn PW, Macintyre IG. 1977. Growth rate and age of coral reefs on the Pacific coast of Panama. Proc. 3rd Int. Coral Reef Symp. 2: 251-259.

Goldber WM. 2013. The Biology of Reefs and Reef Organisms. University of Chicago Press, Chicago, $387 \mathrm{pp}$.

Guzmán HM, Cortés J. 1989a. Growth rates of eight species of Scleractinian corals in the Eastern Pacific (Costa Rica). Bull. Mar. Sci. 44: 1186-1194.

Guzmán HM, Cortés J. 1989b. Coral reef community structure at Caño Island, Pacific Costa Rica. P.S.Z.N.I: Mar. Ecol. 10: 23-41.

Guzmán HM, Cortés J. 1992. Cocos Island (Pacific of Costa Rica) coral reefs after the 1982-83 El Niño disturbance. Rev. Biol. Trop. 40: 309-324.

Hawkins CM. 1981. Efficiency of organic matter absorption by the tropical echinoid Diadema antillarum Philippi fed nonmacrophytic algae. J. Exp. Mar. Biol. Ecol. 49: 245-253.

Herrera-Escalante T, López-Pérez RA, Leyte-Morales GE. 2005. Bioerosion caused by the sea urchin Diadema mexicanum
Pacífico del sur de México no difiere, o se encuentran ligeramente por debajo, de los valores registrados para otros sistemas arrecifales del Pacífico Oriental Tropical (Alvarado y Fernández 2005, Herrera-Escalante et al. 2005, BenítezVillalobos et al. 2008, Alvarado et al. 2012). En el área de estudio, se observaron diferencias significativas en la densidad de $D$. mexicanum a distintas escalas espaciales. De acuerdo con nuestros resultados, la distribución espacial de la densidad y talla de $D$. mexicanum en la zona de estudio pudiera estar explicada por la variación en el tipo de sustrato. En particular, la mayor densidad y talla de D. mexinanum se encontró en aquellos sitios donde la cobertura de corales y algas fue más baja y donde la cobertura de roca fue mayor. Estos resultados pueden dar indicios acerca de los potenciales efectos, presentes y futuros, de la bioerosión de D. mexicanum en las comunidades y arrecifes coralinos de las costas del Pacífico del sur de México. En general, los mayores niveles de bioerosión por la actividad alimenticia de D. mexicanum se observaron en Puerto Ángel (Oaxaca) y los menores en Ixtapa-Zihuatanejo (Guerrero). De continuar los presentes niveles de uso y estado de conservación de los sistemas coralinos frente a las costas suoccidentales de México, podríamos esperar una bioerosión cada vez más importante en las comunidades y arrecifes en el área de Puerto Ángel (Oaxaca), en particular en sitios como La Tijera y Playa del Muerto en donde se observan importantes secciones $(>30 \%)$ de coral muerto.

Finalmente, el presente recuento de bioerosión sólo incluye el efecto potencial de la actividad alimenticia de D. mexicanum sobre comunidades y arrecifes coralinos frente a las costas sudoccidentales de México, pero deja de lado la bioerosión asociada a la abrasión mecánica de las espinas de los erizos (Herrera-Escalante et al. 2005). De manera adicional, los datos de bioerosión de las comunidades y arrecifes coralinos del Pacífico sur mexicano aquí presentados deben ser considerados parciales, pues no consideran la bioerosión por esponjas (Nava y Carballo 2008; Carballo et al. 2008, 2013), peces (Ong y Holland 2010), moluscos y otros macro y micro bioerosionadores (Perry et al. 2012) que contribuyen de manera importante a la remoción de carbonatos de los ecosistemas arrecifales.

\section{AgRADECIMIENTOS}

El presente trabajo fue financiado a través de fondos otorgados a ALP por el Consejo Nacional de Ciencia y Tecnología (CONACYT, México, proyectos 80228 y 236654) y la Universidad Autónoma Metropolitana (PRODEP UAMPTC-509). DALL obtuvo apoyo financiero por parte del CONACYT (CVU 477189). Agradecemos a Eladio Spindola y Andrés Pacheco (Universidad del Mar) su disposición durante el trabajo de campo. 
(Echinodermata: Echinoidea) at Bahías de Huatulco, western Mexico. Rev. Biol. Trop. 53(3): 263-273.

Hughes TP. 1987. Skeletal density and growth form of corals. Mar. Ecol. Prog. Ser. 35: 259-266.

Hughes TP, Reed DC, Boyle MJ. 1987. Herbivory on coral reefs: Cummunity structure following mass mortalities of sea urchins. J. Exp. Mar. Biol. Ecol. 113: 39-59.

Hutchings P. 2008. Role of polychaetes in bioerosion of coral substrates. In: Wisshak M, Tapanila L (eds.), Current Developments in Bioerosion. Part II. Springer, Berlin, pp. 249-264.

Jiménez C, Cortés J. 2003. Growth of seven species of Scleractinian corals in an upwelling enviroment of the Eastern Pacific (Golfo de Papagayo, Costa Rica). Bull. Mar. Sci. 72: 187-198.

Kiene WE, Hutchings PA. 1994. Bioerosion experiments at Lizard Island, Great Barrier Reef. Coral Reefs 13: 91-98.

Levitan DR. 1988. Algal-urchin biomass responses following mass mortality of Diadema antillarum Philippi at Saint John, US Virgin Islands. J. Exp. Mar. Biol. Ecol. 119: 167-178.

Leyte-Morales GE. 1997. La colección de corales de la Universidad del Mar. Ciencia y Mar. 1: 3-16.

López-Pérez A, Granja-Fernández R, Aparicio-Cid C, ZepetaVilchis RC, Torres-Huerta AM, Benítez-Villalobos F, LópezLópez DA, Cruz-Antonio C, Valencia-Méndez O. 2014. Stony corals, echinoderms and fish associated to coral communities and reefs from the Parque Nacional Huatulco, southern Mexican Pacific. Rev. Mex. Biodiv. 85(4):1145-1159.

López-Pérez RA, Calderón-Aguilera LE, Reyes-Bonilla $\mathrm{H}$, Carriquiry JD, Medina-Rosas P, Cupul-Magaña AL, HerreroPérezrul MD, Hernández-Ramírez HA, Ahumada-Sempoal MA, Luna-Salguero BM. 2012. Coral communities and reefs from Guerrero, southern Mexican Pacific. Mar. Ecol. 33: 407-416.

López-Pérez RA, Hernández-Ballesteros LM. 2004. Coral community structure and dynamics in the Huatulco area, western Mexico. Bull. Mar. Sci. 75: 453-472.
Nava H, Carballo JL. 2008. Chemical and mechanical bioerosion of boring sponges from Mexican Pacific coral reefs. J. Exp. Biol. 211: 2827-2831.

Ong L, Holland KM. 2010. Bioerosion of coral reefs by two Hawaiian parrotfishes: Species, size differences and fishery implications. Mar. Biol. 157: 1313-1323.

Perry CT, Edinger EN, Kench PS, Murphy GN, Smithers SG, Steneck RS, Mumby PJ. 2012. Estimating rates of biologically driven coral reef framework production and erosion: A new census-based carbonate budget methodology and applications to the reefs of Bonaire. Coral Reefs 31: 853-868.

Reaka-Kudla ML, Feingold JS, Glynn W. 1996. Experimental studies of rapid bioerosion of coral reefs in the Galapagos Islands. Coral Reefs 15: 101-107.

Reyes-Bonilla H, Calderón-Aguilera LE. 1999. Population density distribution and consumption rates of three corallivores at Cabo Pulmo reef, Gulf of California, Mexico. Mar. Ecol. 20(3-4): 347-357.

Reyes-Bonilla H, Leyte-Morales GE. 1998. Corals and coral reefs of the Puerto Angel region, west coast of Mexico. Rev. Biol. Trop. 46(3): 679-681.

Sammarco PW. 1980. Diadema and its relationship to coral spot mortality: Grazing, competition, and biological disturbance. J. Exp. Mar. Biol. Ecol. 45: 245-272.

Santiago-Valentín JD, Rodríguez-Troncoso AP, Carpizo-Ituarte E, Benítez-Villalobos F, Torres-Hernández P, López-Pérez A. 2015. Reproductive pattern of the reef-building coral Pavona gigantea (Scleractinia: Agariciidae) off southwestern Mexico = Patrón reproductivo del coral arrecifal Pavona gigantea (Scleractinia: Agariciidae) frente al sudoeste de México. Cienc. Mar. 41(3): 233-246. http://dx.doi.org/10.7773/cm.v41i3.2482

Woodley JD. 1999. Sea urchin exert top-down control of macroalgae on Jamaican coral reefs. Coral Reefs 18: 192-193.

Zar JH. 2009. Biostatistical Analysis. Prentice Hall, New Jersey, $663 \mathrm{pp}$.

Received September 2015, accepted February 2016. 